\title{
STRATEGI MANAJER KAMPANYE BAGI KOMUNIKATOR POLITIK
}

\author{
Chontina Siahaan \\ Siahaan.Chontina@yahoo.com
}

\begin{abstract}
In the political life, a political communicator has a central role when he or she want to get a position in the parliament either as president or vice president in the legislative, executive or judicative branch. A strategic planning of the Campaign Manager is very important to bring a Political Communicator to be president. What has to be done by a campaign manager and what kind of strategy will be used to achieve its goal will be described in this article by mapping steps conducted by the Campaign Manager that using PEST and SWOT analysis and followed by campaign planning to answer five basic questions: what will be achieved, who is the target, what message will be conveyed, how to convey, how to evaluate and time and fund of its implementation.
\end{abstract}

Keywords: Political communicator, Campaign manager, Strategic planning

\section{Pendahuluan}

Tulisan ini ingin mengetahui bagaimana strategi manager kampanye dalam menghantar seorang kandidat menduduki jabatan sebagai presiden. Untuk itu, terlebih dahulu dijelaskan bagaimana perbedaan pemilu presiden sebelum dan sesudah pemerintahan Soesilo Bambang Yudhoyono atau SBY.

Pada era orde lama dan orde baru, cara pemilihan presiden masih dilakukan oleh anggota DPR dan MPR sehingga pada waktu itu, manager kampanye belum dibutuhkan karena yang memilih presiden adalah anggota DPR dan MPR. Artinya, presiden tidak dipilih secara langsung oleh masyarakatnya. Oleh karena itu, sistem pemilihan umum selama beberapa periode masih ditentukan oleh lembaga negara. Pada waktu itu, masyarakat cukup memilih gambar partai bukan orangnya. Akan tetapi seiring dengan perkembangan perpolitikan di Indonesia, sistem pemilihan presiden mulai tahun 2004 berubah dari sistem pemilu melalui perwakilan menjadi sistem pemilihan langsung. Dari tiga partai menjadi banyak partai, dari sistem memilih hanya kandidat presiden menjadi sistem satu paket yaitu memilih presiden dan wakil presiden serta dimungkinkan pemilihan dari satu putaran menjadi dua putaran.

Perubahan sistem pemilihan umum ini tentu akan membawa perubahan juga dalam sistem perekrutan calon kandidat presiden dan wakil presiden sehingga ketika kita memilih calon presiden dan wakil presiden, kita sudah mengetahui siapa orangnya, apa visi dan misinya dan bagaimana kredibilitas serta 
track recordnya. Demikian juga di pihak masyarakat sebagai pemilih, ikut mengalami perubahan tentang sistem pemilu antara lain, dari sistem menusuk gambar, menjadi mencontreng. Sebelum tahun 2004 masyarakat cukup memilih presiden dari gambar partai yang tersedia. Tapi setelah tahun 2004, masyarakat harus memilih anggota DPR di tingkat Pusat dan Daerah dengan memilih gambar calon yang tersedia.Sehingga banyak pemilih memilih anggota DPR, DPRD hanya berdasarkan gambar yang ganteng, cantik, atau karena artis yang sudah dikenal karena mereka tidak mengenal calon-calon tersebut. Masyarakat tidak dapat disalahkan karena memang pendidikan politik tidak diberikan terlebih dahulu kepada masyarakat sebelum menentukan pilihannya.

Dengan perubahan pada sistem pemilu ini, maka berubah pulalah peta perpolitikan di Indonesia mulai dari pendaftaran parpol yang sangat bervariasi, cara berkampanye dan cara melakukan pemilihan presiden dan wakil presiden. Demikian juga cara pelaksanaan pemilu mulai dari yang konstitusional sampai yang tidak konstitusional. Mulai dari sistem pemilihan yang berlangsung luber sampai dengan praktek-praktek pemilihan yang curang. Masyarakat sebagai peserta pemilih, mau tidak mau harus menyesuaikan diri dengan sistem yang baru. Masyarakat ikut bingung dengan perubahan sistem pemilu tersebut karena masyarakat kita masih kurang memahami budaya politik di Indonesia. Almond dan Verba mendefinisikan budaya politik sebagai suatu sikap orientasi yang khas warga negara terhadap sistem politik dan aneka ragam bagiannya, dan sikap terhadap peranan warga negara di dalam sistem itu. Almond dan Verba melihat bahwa dalam pandangan tentang obyek politik, terdapat tiga komponen, yaitu komponen koqnitif, afektif, dan evaluatif. Menurut mereka kita akan dapat mengukur bagaimana sikap individu atau masyarakat terhadap sistem politik dengan menggunakan ketiga komponen ini.(Alfian, 1991: 21).

Di samping orientasi terhadap sistem politik, pandangan atau sikap sesama warga negara juga merupakan suatu aspek budaya politik penting lainnya. Sikap atau pandangan ini berkaitan dengan "rasa percaya" (trust) dan "permusuhan" (hostility) yang biasanya memang terdapat antara warga negara yang satu dengan golongan lainnya dalam masyarakat.

Seiring dengan perubahan sistem pemilihan presiden tersebut, maka caracara atau upaya untuk memenangkan calon kandidat juga berbeda. Misalnya, para kandidat menyampaikan visi misinya dan program kerjanya melalui media televisi yang sudah ditentukan waktu dan jadwal mereka tayang di media televisi, waktu dan tempat kampanye bagi masing-masing partai. Oleh karena itu, untuk mengatur dan menyiapkan berbagai persiapan kampanye, dibutuhkan seorang manager kampanye yang benar-benar dapat mengatur strategi bagaimana memenangkan pemilu. Debat terbuka di antara calon presiden dimungkinkan dalam era reformasi sehingga, masyarakat mengetahui bagaimana cara kerja calon presiden kelak jika dia terpilih. Untuk mencapai semua tujuan ini, maka kehadiran seorang manager kampanye sangat dibutuhkan bahkan dibayar mahal. Contoh, saat presiden SBY mencalonkan diri menjadi presiden RI periode 2004, yang 
menjadi manger kampanye beliau adalah Heroe Syswanto Ns yang akrab disapa Sys Ns. Sys berada di garda depan kampanye presiden pada 2004.

Pemilihan presiden di Indonesia dilakukan 5 tahun sekali tetapi kenyataannya, belum selesai masa jabatan presiden terpilih, sudah ada orangorang tertentu yang mengkampanyekan partai baru yang nanti akan ikut berkompetisi dalam pemilihan presiden mendatang. Misalnya, pendeklarasian partai Nasional Demokrat. Partai ini sudah sejak beberapa tahun yang lalu sudah aktif mengkampanyekan ormasnya di seluruh Indonesia dengan harapan, khalayak dapat mengetahui bahwa ada partai baru yang ikut pemilihan presiden tahun 2014. Partai baru ini perlu disosialisasikan sedini mungkin supaya masyarakat Indonesia mengetahui keberadaan partai baru tersebut.

Dalam Negara demokratis, partai politik menyelenggarakan beberapa fungsi yaitu:

1. Partai sebagai sarana komunikasi politik.

Salah satu tugas dari partai politik adalah menyalurkan aneka ragam pendapat dan aspirasi masyarakat dan mengaturnya sedemikian rupa sehingga kesimpangsiuran pendapat dalam masyarakat berkurang.

2. Partai sebagai sarana sosialisasi politik

Partai politik juga main peranan sebagai sarana sosialisasi politik (instrument of political socialization). Di dalam ilmu politik sosialisasi politik diartikan sebagai proses melalui mana seseorang memperoleh sikap dan orientasi terhadap phenomena politik, yang umumnya berlaku dalam masyarakat di mana ia berada.

3. Partai politik sebagai sarana rekruitmen politik

Partai politik juga berfungsi untuk mencari dan mengajak orang yang berbakat untuk turut aktif dalam kegiatan politik sebagai anggota partai (political recruitment). Dengan demikian partai turut memperluas partisipasi politik.

4. Partai politik sebagai sarana pengatur konflik (conflict management)

Dalam suasasana demokrasi, persaingan dan perbedaan pendapat dalam masyarakat merupakan soal yang wajar. Jika sampai terjadi konflik, partai politik berusaha untuk mengatasinya. (Budiardjo, 1993,:163-164)

Di dalam pembentukan sosialisasi politik, ada 3 anggapan yang dibuat yaitu:

a. Pengalaman sosialisasi yang akan memengaruhi tingkah laku politik di kemudian hari yang terjadi sebelumnya dalam kehidupan.

b. Pengalaman ini bukan pengalaman yang bersifat politik, tetapi memiliki berbagai konsekuensi poitik laten yaitu yang tidak dimaksudkan melahirkan impact politik sedang impact tersebut tidak terorganisir adanya; 
c. Proses sosialisasi selalu bersifat unidireksional: di mana pengalamanpengalaman mendasar di dalam keluarga mempunyai pengaruh penting terhadap struktur sekunder politik tetapi sebaliknya tidak dipengaruhi oleh politik.(Almond, 1984:325).

Saya mengutip pendapat Gregory, 2000; Simons, 1990 dalam (Antar Venus, 2009:144) bahwa sebuah perencanaan untuk menghantar seseorang menjadi komunikator politik harus dilakukan dalam sebuah kampanye dengan alasan sebagai berikut: Memfokuskan usaha perencanaan membuat tim kampanye dapat mengidentifikasi dan menyusun tujuan yang akan dicapai dengan benar hingga akhirnya pekerjaan dapat dilakukan secara efektif dan efisien, karena berkonsentrasi pada prioritas dan alur kerja yang jelas antara lain:

a. Mengembangkan sudut pandang berjangka waktu panjang.

Perencanaan membuat tim kampanye melihat semua komponen secara menyeluruh. Ini akan membuat tim kampanye tidak berfikir mengenai efek kampanye dalam jangka waktu yang pendek tapi juga ke masa depan, hingga mendorong dihasilkannya program yang terstruktur dalam menghadapi kebutuhan masa depan.

b. Meminimalisasi kegagalan

Perencanaan yang cermat dan teliti akan menghasilkan alur serta tahapan kerja yang jelas, terukur dan spesifik serta lengkap dengan langkah-langkah alternatif, sehingga bila ada kegagalan bisa langsung diambil alternatif penyelesaian.

c. Mengurangi konflik

Konflik kepentingan dan prioritas merupakan hal yang sering terjadi dalam sebuah kerja tim. Perencanaan yang matang akan mengurangi potensi munculnya konflik, karena sudah ada bentuk tertulis mengenai alur serta prioritas pekerjaan untuk tiap-tiap anggota tim.

d. Memperlancar kerja sama dengan pihak lain

Sebuah rencana yang matang akan memunculkan rasa percaya para pendukung potensial serta media yang akan digunakan sebagai saluran kampanye, hingga pada akhirnya akan terjadi kerja sama yang baik dan lancar.

Kampanye merupakan salah satu metode komunikasi (persuasi), karena di sini juga membahas tentang upaya mempengaruhi massa, baik dalam tingkah laku maupun dalam bentuk opini. Kampanye akhirnya harus berfungsi melalui individu-individu yang menerima dan menanggapi pesan dan karenanya banyak syarat dampak yang telah diuraikan juga berlaku bagi kampanye (McQuail, 1987:242). 
Sebelum membuat perencanaan kampanye, seorang manager kampanye melakukan analisis masalah dan menyusun tujuan terlebih dahulu agar perencanaan kampanye dapat lebih baik dan matang.

Ada 2 jenis analisis yang digunakan untuk perencanaan program kampanye yaitu analisis PEST (Political, Economic, Social and Technology) yang secara khusus mempertimbangkan empat aspek penting yang terkait langsung dengan proses pelaksanaan kampanye. Kemudian analisis SWOT (Strength, Weaknesess, Opportunity and Threats) yang lebih memfokuskan diri pada kalkulasi peluang pencapaian tujuan kampanye. (Venus, 2009:146)

Perencanaan di atas dapat digambarkan sebagai berikut:

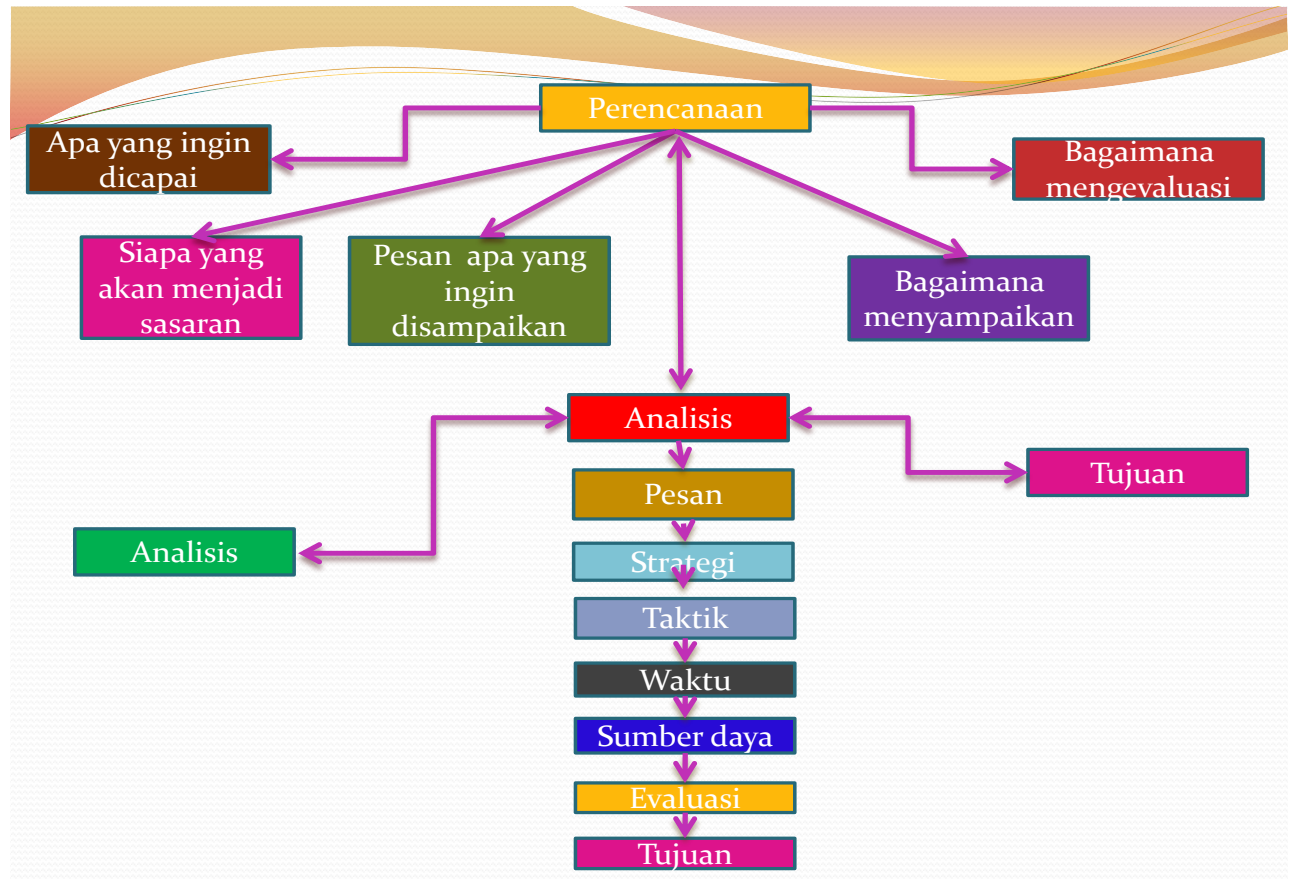

Strategi penyusunan rencana kampanye dapat disusun dengan mengajukan beberapa pertanyaan yaitu:

1. Apa yang ingin dicapai

2. Siapa yang akan menjadi sasaran

3. Pesan apa yang ingin disampaikan

4. Bagaimana menyampaikannya

5. Bagaimana mengevaluasinya

Kelima pertanyaan tersebut dapat dituangkan ke dalam tahap-tahap perencanaan seperti digambarkan di bawah ini. 


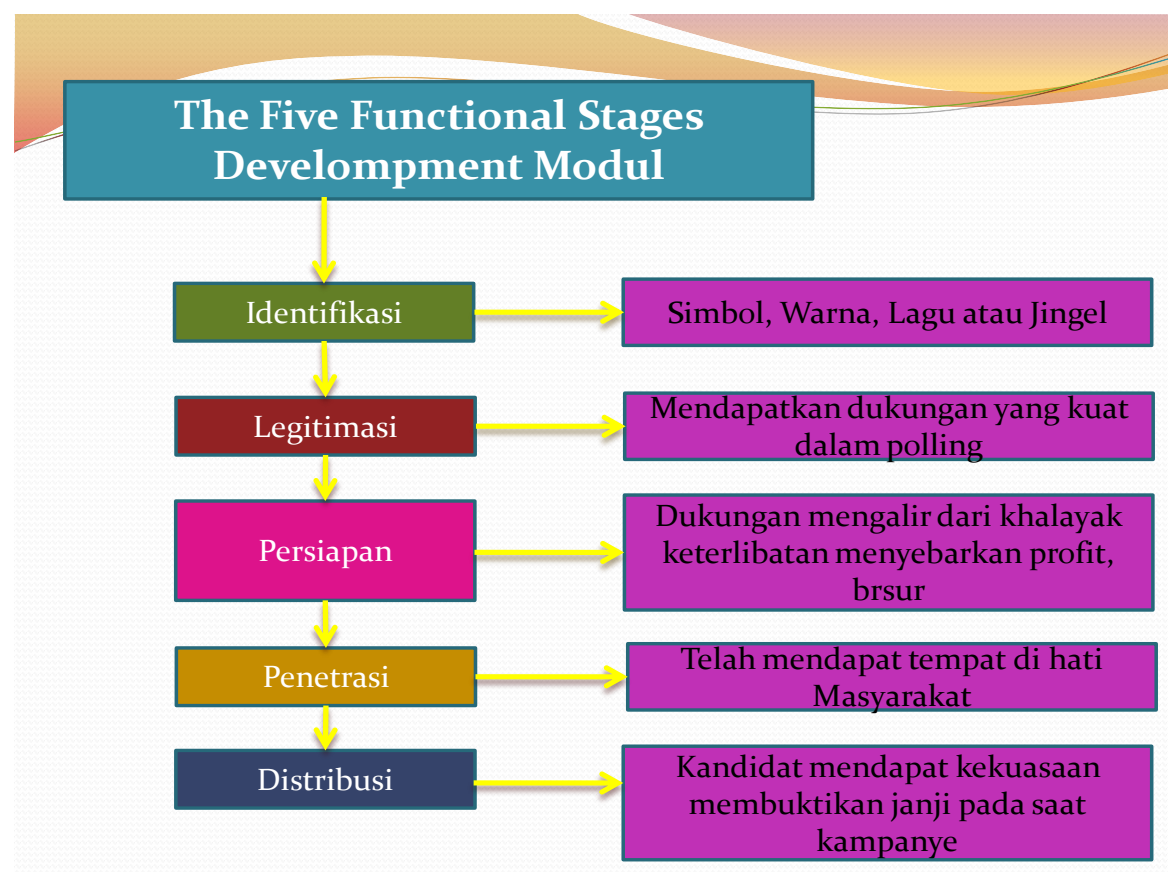

Sumber: Antar Venus, 2009

Dengan melihat gambar di atas, seorang manager kampanye dapat menyederhanakan cara berpikir semua masyarakat yang akan dijadikan menjadi juru kampanye baik mulai dari tingkat RT, Kelurahan, Kecamatan, tingkat daerah, propinsi dan di ibu kota dengan menjabarkan tahap demi tahap apa yang ingin dilakukan.

\section{APA YANG INGIN DICAPAI}

Sebagai Manager kampanye pasti menginginkan agar perjalanan karir komunikator politik menuju kursi presiden periode 2014-2019 dapat terwujud dengan baik. Untuk mencapai target itu, perlu dikampanyekan dulu siapa komunikator politik, bagaimana latar belakangnya dan prestasi-prestasi apa yang sudah diperoleh baik sebagai politisi, dan pengusaha. Kampanye memperkenalkan lebih jauh komunikator politik dilakukan tidak hanya pada saat pemilihan presiden akan tetapi sudah dimulai jauh sebelum acara pemilihan kandidat presiden. Untuk pemilihan presiden tahun 2014, seorang komunikator politik idealnya sudah mulai memperkenalkan partainya tahun 2009 secara terus menerus supaya tumbuh kesadaran masyarakat dan dapat membentuk opini publik maupun membuat polling tentang keberadaan komunikator politik. Dengan mengkampanyekan komunikator politik lebih awal tentang program, visi 
dan misi, tentu masyarakat lebih familiar tentang komunikator politik apa lagi dilakukan di seluruh propinsi.

Bagi Manager Kampanye, perlu mengetahui siapa komunikator politik sebenarnya, apa kekuatan dan kelemahannya, bagaimana visi dan misinya, seberapa besar kekuatannyanya di masyarakat dan seberapa jauh dikenal oleh masyarakat. Untuk menganalisis masalah ini, seorang manager kampanye dapat menerapkan model "The five fungsional stages development model" yang terdiri dari: Identifikasi, Legitimasi, Partisipasi, Penetrasi, Distribusi.(Venus, 2009:18). Model ini dapat diterapkan dalam kampanye untuk memenangkan komunikator politik, karena itu, manager kampanye dapat mengawalinya dengan memaparkan siapa kandidat yang calonkan. Sebagai contoh, misalnya, yang ingin dicalonkan menjadi kandidat presiden tahun 2014-2019 adalah Surya Paloh, maka hal-hal yang berhubungan dengan Surya Paloh harus sudah diperkenalkan sejak awal, misalnya:

\section{a. Identitas Surya Paloh, Simbol Partai Nasdem, Makna Logo, warna baju, lagu atau jinggle Nasdem}

\subsection{Legitimasi}

Dalam kampanye politik, legitimasi diperoleh ketika seseorang telah masuk dalam daftar kandidat anggota legislatif, atau seorang kandidat presiden memperoleh dukungan yang kuat dalam polling yang dilakukan lembaga independen. Misalnya, Surya Paloh adalah kandidat-kandidat yang memiliki legitimasi masyarakat ketika mereka menempati urutan teratas dalam pengumpulan pendapat yang diselenggarakan SCTV pada bulan Desember 2003. Para pejabat politik yang sedang berkuasa juga memiliki legitimasi, tapi hal itu diperoleh secara otomatis karena faktor jabatan. Legitimasi mereka bisa efektif digunakan dan dipertahankan sejauh mereka dianggap capable (cakap) dan tidak menyalahgunakan jabatan. Hasil polling ini akan selalu saya kemukakan agar terbentuk opini publik bahwa kandidat Surya Paloh layak dipilih menjadi presiden periode 2014-2019.

\section{I.3 Partisipasi}

Tahap ini dalam praktiknya relatif sulit dibedakan dengan tahap legitimasi karena ketika seorang kandidat mendapatkan legitimasi, pada saat yang sama dukungan yang bersifat partisipatif mengalir dari khalayak. Partisipasi ini bisa bersifat nyata (real) atau simbolik. Partisipasi nyata ditunjukkan oleh keterlibatan orang-orang dalam menyebarkan pamflet, brosur atau poster, menghadiri demonstrasi yang diselenggarakan sebuah lembaga swadaya masyarakat atau memberikan sumbangan untuk perjuangan partai. Sementara partisipasi simbolik bersifat tidak langsung, misalnya ketika anda menempelkan stiker partai di kaca belakang mobil anda, atau sekedar menggunakan kaos Nasdem. Kegiatan ini dapat disebarluaskan melalui media televisi sehingga masyarakat mengetahi 
betapa banyak orang yang sudah bergabung dengan Nasdem. Jadi setiap ada kegiatan Nasdem baik di tingkat pusat sampai ke daerah harus selalu diinformasikan.

\section{I.4 Penetrasi}

Sebuah gagasan telah hadir dan telah mendapat tempat di hati masyarakat. Seorang juru kampanye misalnya, telah berhasil menarik simpati masyarakat dan meyakinkan mereka bahwa Surya paloh adalah kandidat terbaik dari sekian yang ada. Atau sebuah kampanye yang ditujukan untuk menentang kebijakan pemerintah mendapat tanggapan serius pemerintah dengan membuka dialog untuk mencari jalan keluar terbaik.

\section{I.5 Distribusi atau pembuktian}

Pada tahap ini tujuan kampanye pada umumnya telah tercapai. Kandidat politik telah mendapatkan kekuasaan yang mereka cari. Tinggal mereka menerapkan janjinya ketika kampanye. Bila mereka gagal melakukan itu maka akibatnya akan fatal bagi kelangsungan jabatan atau gagasan yang telah diterima masyarakat.

\section{SIAPA YANG AKAN MENJADI SASARAN}

Yang menjadi sasaran kita untuk memenangkan Komunikator Politik menjadi presiden tentu seluruh masyarakat Indonesia. Akan tetapi biar bagaimana pun perlu sasaran bidik kita mengenai sasaran karena tidak semua lapisan masyarakat mengikuti perkembangan perpolitikan di Indonesia. Oleh karena itu, sasaran bidik bisa dibagi sebagai berikut: (Nimmo, 1989:144)

1. Komunikator Politik (politikus, baik representatif maupun ideologi)

2. Pengikut politik (mereka yang menaruh minat aktif dalam politik)

3. Bukan pengikut politik (mereka yang tidak tahu menahu tentang urusan politik

4. Juru bicara kelompok terorganisasi dan pemuka pendapat

5. Mereka yang atentif,(mengambil bagian dalam politik dengan berbagai cara)

6. Menaruh minat,(membatasi keterlibatan mereka terutama pada upaya agar selalu memperoleh informasi dan pada pemberian suara

7. Acuh tak acuh terhadap politik adalah inti kelompok bukan pengikut

Dapat juga dilakukan berdasarkan pelapisan sasaran yaitu:

a. Sasaran utama (sasaran yang akan dibidik yang paling potensial, yang dalam istilah lain disebut ultimate targets

b. Sasaran lapis satu, (intermediate targets)

c. Sasaran Lapis dua dan seterusnya 
Arens (1999) mengatakan segmentasi sasaran kampanye dilaksanakan dengan melakukan pemilahan atau segmentasi terhadap:

a. kondisi geografis (geographic sementation) yang berkaitan dengan ukuran atau luas daerah, lokasi spesifik, jenis media serta budaya komunikasi di daerah tempat tinggal sasaran.

b. kondisi demografis (demographic segmentation), dilakukan dengan melihat karakteristik jenis kelamin, usia, suku, pendidikan,pekerjaan, dan pendapatan sasaran.

c. kondisi perilaku (behavioristic segmentation), dan kondisi psikografis (psychographyc segmentation) dilakukan dengan melihat status, gaya hidup, dan jenis perilaku lainnya

d. phsycographic segmentation dilakukan dengan melihat emosi serta nilai budaya yang dianut oleh publik.

\section{PESAN APA YANG DISAMPAIKAN}

Pesan perlu dikemas dengan baik agar masyarakat dapat mengerti tentang pesan yang disampaikan. Pesan tidak boleh ambigu, dan pesan sebaiknya menarik. Misalnya, pesan Partai Nasdem adalah "Restorasi” atau perubahan. Pesan ini harus terus-menerus disampaikan sampai melekat di benak masyarakat. Pesan juga perlu jelas dan tidak ambigu.

Ada 4 tahap yang perlu dilakukan dalam merencanakan pesan dan menurunkannya dari tema kampanye yaitu:

1. Mengambil persepsi yang berkembang di masyarakat berkenaan dengan issu yang akan dikampanyekan

2. Mencari celah di mana kita bisa masuk dan mengubah persepsi

3. Melakukan identifikasi elemen-elemen persuasi. Kita bisa menggunakan jalur utama maupun jalur alternatif

4. Meyakinkan bahwa pesan sudah layak untuk disampaikan dalam program kampanye, ujicoba, dapat dilakukan dengan menggunakan pemilihan sample dari populasi yang kita uji.

\section{MEMAHAMI HAKEKAT KAMPANYE}

Menurut Rogers dan Storey (1987), kampanye sebagai serangkaian tindakan komunikasi yang terencana dengan tujuan menciptakan efek tertentu pada sejumlah besar khalayak yang dilakukan secara berkelanjutan pada waktu kurun waktu tertentu. Dengan demikian kampanye pada prinsipnya adalah contoh tindakan persuasi secara nyata. Dalam ungkapan Perloff (1993) dikatakan "campaign generally exemplify persuasion in action" (Antar Venus, 2009:7)

Jenis kampanye untuk Komunikator politik, misalnya dapat dipilih Candidate-oriented campaigns atau kampanye yang berorientasi pada kandidat. Umumnya dimotivasi oleh hasrat untuk meraih kekuasaan politik. Karena itu jenis kampanye ini dapat pula disebut sebagai political campaigns (kampanye politik). Tujuannya antara lain adalah untuk memenangkan dukungan 
masyarakat terhadap kandidat-kandidat yang diajukan partai politik agar dapat menduduki jabatan-jabatan politik yang diperebutkan lewat proses pemilihan umum.

Orang yang bercita-cita untuk dan atau memegang jabatan pemerintah harus dan memang berkomunikasi tentang politik. Kita menamakan calon atau pemegang jabatan ini politikus, tak peduli apakah mereka dipilih, ditunjuk, atau pejabat karir, dan tidak mengindahkan apakah jabatan itu eksekutif, legislatif atau judikatif.(Nimmo, 1993:30)

Kampanye merupakan upaya sistematis untuk memengaruhi khalayak, terutama calon pemilih. Tujuannya, agar calon pemilih memberikan dukungan atau suaranya kepada partai politik atau kandidat yang sedang berkompetensi dalam suatu pemilihan. Pemilihan yang dimaksud adalah pemilihan presiden dan wakil presiden dan pemilihan di tingkat daerah, baik eksekutif ataupun legislatif.(Pawito, 2008:210).

Organisasi tim kampanye melibatkan orang-orang yang diyakini cakap pada bidangnya masing-masing - menyangkut kepemimpinan dan sumber daya manusia) dan dukungan dana. Perencanaan dan strategi kampanye termasuk penentuan positioning, segmentasi target. Perumusan issu, strategi media, pemilihan endorser atau bintang iklan yang sekaligus diharapkan berfungsi untuk meningkatkan brand image dan pemahaman mengenai perilaku khalayak pemilih.

Pelaksanaan yang konsisten kendati tetap mempertimbangkan perkembangan situasi. Monitoring dan evaluasi yang berkelanjutan melekat pada sistem manajemen kampanye sambil terus menerus mengupayakan optimalisasi dan penyempurnaan.

\section{Pengaruh Kredibilitas Sumber Terhadap kampanye}

a) Keterpercayaan (trustworthiness) berkaitan dengan penilaian khalayak bahwa sumber informasi dianggap tulus, jujur, bijak dan adil, objektif, memiliki integritas pribadi, serta memiliki tanggungjawab sosial yang tinggi. Khalayak akan menilai apakah pelaku kampanye dapat dipercaya atau apakah secara moral mereka dapat diandalkan. Penilaian yang dilakukan umumnya berpatokan pada perilaku sumber pada masa lalu dan dugaan khalayak tentang perilakunya pada saat sekarang. Dengan kata lain track record seseorang akan menjadi acuan apakah yang bersangkutan dianggap memiliki keterpercayaan atau tidak. Masyarakat akan menilai bagaimana keterpercayaan masing-masing kandidat calon presiden karena keterpercayaan berkaitan dengan penilaian khalayak.

b) Keahlian (ekspertise) berhubungan dengan penilaian dimana sumber dianggap berpengetahuan, cerdas, berpenglaman, memiliki kewenangn tertentu dan menguasai skill yang bisa diandalkan. Untuk dikatakan ahli tidak perlu memiliki semua kualitas di atas satu atau dua sifat saja 
umumnya dianggap sudah mencukupi. Dalam konteks kampanye, keahlian pelaku kampanye di mata khalayak dapat merentang dari kategori ahli hingga tidak ahli. Jika khalayak memersepsi komunikator sebagai orang yang ahli maka mereka cenderung bersedia mendengarkan, mempelajari dan menerima isi pesan yang disampaikan. Sebaliknya, bila komunikator dipandang tidak memiliki keahlian maka khalayak akan mengabaikan pesan tersebut. Dalam istilah Stone dkk (1999) dikatakan "receivers simply avoid exposure to a source who is viewed as incompetent".

c) Daya Tarik Sumber termasuk variabel yang paling banyak dimanfaatkan oleh kalangan praktisi periklanan, kampanye politik dan public relations dalam mengefektifkan pesan-pesan yang mereka sampaikan. Secara umum konsep ini meliputi penampilan fisik dan identifikasi psikologis.(Venus, 2009:59-60).

\section{BAGAIMANA MENYAMPAIKAN PESAN}

Banyak cara untuk menyampaikan pesan kepada khalayak dan ini dapat kita lihat dari tujuan komunikasi politik. Menurut Arifin (2003:05) salah satu tujuan komunikasi politik adalah membentuk citra politik yang baik bagi khalayak. Citra adalah serangkaian pengetahuan dan pengalaman serta perasaan (emosi) maupun penilaian yang diorganisasikan ke dalam sistem koqnisi manusia, atom pengetahuan pribadi yang sangat diyakini kebenarannya. Jadi citra politik dapat dipahami sebagai gambaran seseorang yang terkait dengan politik (kekuasaan, kewenangan, otoritas, konflik, dan konsensus). Citra politik berkaitan dengan pembentukan pendapat umum karena pada dasarnya pendapat umum politik terwujud sebagai konsekwensi dari koqnisi komunikasi politik. (Ardial,2010:45).

Nimmo (2006:6-7) menjelaskan bahwa citra seseorang yang terkait dengan politik yang terjalin melalui pikiran, perasaan, dan kesucian subyektif akan memberi kepuasan baginya, dan memiliki paling sedikit tiga kegunaan.

1. Memberi pemahaman tentang peristiwa politik tertentu

2. Kesukaan atau ketidaksukaan umum kepada citra seseorang tentang politik menyajikan dasaar untuk menilai objek politik.

3. Citra diri seseorang dalam cara menghubungkan diri dengan orang lain.

\section{Opini Publik}

Selain citra politik, komunikasi politik juga bertujuan membentuk dan membina opini publik (pendapat umum) serta mendorong partisipasi 
politik. Konsep opini publik bertitik tolak dari asasi yang ada pada diri manusia, yaitu hak kebebasan mengeluarkan pendapat, menyatakan kehendak, ide, atau gagasan.

\section{Penggunaan Media}

Jika sudah kita pahami semua identitas dari kandidat presiden, manager kampanye dapat menggunakan media massa untuk lebih memasarkan politik dari Komunikator Politik. Terkait dengan politik adalah fungsi media massa dalam kehidupan politik. Karena sifatnya yang sentral dalam politik, media massa memiliki fungsi penting dan strategis. (Pawito, 2009:93)

Pemilihan media komunikasi harus didasarkan atas sifat isi pesan maksudnya ialah kemasan pesan yang ditujukan untuk memasyarakat luas, pesan sebaiknya disalurkan melalui media massa misalnya surat kabar atau televisi, dan untuk komunitas tertentu digunakan media selebaran atau saluran komunikasi kelompok(Cangara, 2009:375).

Pemilihan media komunikasi harus memerhatikan hal-hal berikut:

1. Sumber daya komunikasi yang tersedia di suatu tempat, dengan cara:

- Kumpulkan data berapa banyak stasiun radio, penerbit surat kabar, stasiun tv dan berapa banyak jumlah dan jenis surat kabar yang beredar dalam masyarakat.

- Analisis status sumber daya komunikasi, apakah stasiun TV dan radio yang ada milik swasta atau pemerintah, siapa penerbit surat kabar harian dan mingguan yang ada.

- Membuat analisi kritis yang dibutuhkan masyarakat terhadap media, informasi apa yang mereka perlukan, dan bagaimana pendapat atau komentar mereka.

2. Pemilikan media di kalangan masyarakat sasaran, berapa banyak penduduk, yang memiliki pesawat televisi, tv kabel, radio dan pelanggan suat kabar.

3. Terjangkau tidaknya pesan yang akan disampaikan, apakah semua siaran televisi dapat diterima oleh pemirsa di suatu provinsi, apakah pelangan surat kabar hanya terbatas di kota atau ada juga di desadesa.

\section{V.1 Media Cetak}

Media Cetak adalah saluran komunikasi di mana pesan-pesan verbalnya (tertulis) maupun dalam bentuk gambar-gambar seperti karikatur dan komik dilakukan dalam bentuk tercetak. Media ini sangat baik disebarluaskan untuk mereka yang bisa membaca dan memiliki waktu senggang yang cukup. Sebuah surat kabar atau media cetak lainnya punya kelebihan, yakni bisa dibaca oleh banyak orang terutama dalam satu rumah tangga, asrama, hotel, atau di perpustakaan. 


\section{V.2 Media Elektronik}

Pesan-pesan pada media elektronik disampaikan melalui getaran listrik yang diterima oleh pesawat penerima tertentu, misalnya televisi dan radio. Kelebihan media massa elektronik adalah bisa menembus ruang dan waktu, sehingga informasinya sangat cepat dan serempak meliputi semua wilayah yang berada dalam radius penerimaan. Selain cepat, pesan-pesan juga disertai gambar hidup yang berwarna sehingga menarik untuk ditonton oleh pemirsa.

\section{V.3 Media Luar Ruang (Outdoor Media)}

Media ini biasa dikaitkan dengan dunia estetika dalam bentuk lukisan dan ditempatkan pada tempat-tempat yang ramai dilihat orang banyak. Jangkauannya terbatas kecuali orang yang lewat dan sempat mencuri perhatian untuk membacanya sekalipun sepintas lalu tetapi memiliki kelebihn karena bisa tahan lama, dan dipindahpindahkan dari satu tempat ke tempat lain. Bentuk-bentuk media luar ruang, antara lain, spanduk, baliho, reklame, iklan bus atau kereta api. Bendera, umbul-umbul, balon dan iklan pohon,

\section{V.4 Media Format Kecil}

Media formar kecil biasanya terdiri atas berbagai macam media, tetapi bentuknya lebih kecil dan isinya kadang terfokus pada satu macam informasi, sudah dibawa kemana-mana dan mudah menarik perhatian orang banyak. Bentuk media format kecil ada dalam bentuk cetakan, lukisan dan artifact lainnya, yakni-buletin, leaflet, selebaran, brosur, poster, kelender, stiker, pin, - lencana kaos oblong, dasi, payung, kantong jinjingan, topi dan sebagainya.

\section{V.5 Saluran Komunikasi Kelompok}

Kebutuhan untuk hidup bermasyarakat menjadi naluri setiap manusia. Oleh sebab itu, manusia tidak bisa dipisahkan dengan kehidupan kelompok baik. Seseorang yang hidup dalam masyarakat minimal ia akan terkait dengan kelompok, baik kelompok partai, kelompok sosial, atau kelompok profesi.

\section{V.6 Saluran Komunikasi Publik}

Ada yang beranggapan bahwa saluran komunikasi publik adalah saluran komunikasi massa sebab ia melibatkan banyak orang. Akan tetapi, ada juga yang menilai bahwa komunikasi publik tidak sama dengan komunikasi massa sebab komunikasi publik sifatnya tatap muka, terbuka, dan langsung, sementara komunikasi massa diantarai oleh media dan tidak bertatap langsung. Saluran komunikasi publik biasanya dalam bentuk rumah ibadah, kampanye terbuka di alun- 
alun, rapat akbar, panggung terbuka di pasar swalayan, pergelaran musik kampus, turnamen olah raga, pasar murah dan lain-lain.

\section{V.7 Saluran Komunikasi Sosial}

Komunikasi sosial dilakukan dalam bentuk tatap muka, tetapi karena sifat pesannya adalah hal-hal yang berkaitan hubungan sosial. Biasanya orang yang terlibat sangat terbatas dalam lingkungan sekitar. Tetapi memiliki intensitas hubungan yang akrab. Misalnya dalam bentuk kelompok arisan, atau pengajian, khtanan, perkawinan, pesta panen dan lain-lain.

\section{V.8 Saluran Komunikasi Antar Pribadi}

Adalah satu bentuk komunikasi yang berlangsung secara tatap muka, tetapi karena pesan-pesannya yang sangat pribadi (privacy) dan tidak boleh didengar orang lain, kecuali mereka yang terlibat langsung dalam komunikasi disebut komunikasi antar pribadi. Saluran komunikasi antarpribadi antara lain surat menyurat, telepon,SMS, anggota keluarga, tetangga dekat, sahabat dan teman kantor,

\section{V.9 Saluran Komunikasi Tradisional}

Misalnya masyarakat Kubu di Jambi, Banten di Lebak, Tengger di Jawa Timur, Dayak di Kalimantan dan lain-lain. Tipe komunikasi tradisional antara lain pesta adat, upacara kelahiran, upacara kematian dan sebagainya.

Dalam kegiatan komunikasi politik, fungsi media massa (media elektronik maupun media cetak) adalah: sumber informasi, fungsi partisipasi, fungsi sosialisasi dan pendidikan politik, fungsi mengembangkan budaya politik dan fungsi integritas bangsa..

Sebagai suber informasi lebih menitikberatkan kepada unsur-unsur berita (News) yang berefek politik. Erick Evert dalam buku "offentichkeit in der Aussen Politik" (Harun, 2006:140) mengemukakan unsur-unsur yang harus dipenuhi dalam pemberitaan politik, yaitu:
(1) Publisitas
(2) Aktualitas
(3) Popularitas.

\section{BAGAIMANA MENGEVALUASI PROGRAM KERJA KAMPANYE}

Evaluasi adalah komponen terakhir dari rangkaian proses pengelolaan kampanye. Evaluasi kampanye diartikan sebagai upaya sistematis untuk menilai berbagai aspek yang berkaitan dengan proses pelaksanaan dan pencapaian tujuan kampanye. Evaluasi dan tinjauan yang akan dilakukan terhadap program kampanye merupakan salah satu bagian dari perencanaan 
kampanye yang tidak boleh terlupakan. Evaluasi berperan penting untuk mengetahui sejauh mana pencapaian yang dihasilkan kampanye.

Terkait dengan pelaksanaan kampanye, terdapat dua hal yang menjadi fokus perhatian yakni:

1. Bagaimana cetak biru kampanye direalisasikan dari waktu ke waktu

2. Bagaimana kinerja pelaksanaan kampanye selama proses kegiatan tersebut berlangsung.

Di samping alasan di atas, Gregory (2000) pakar kampanye Inggris, mengemukakan lima alasan penting lainnya mengapa evaluasi perlu dilaksanakan.

1. Evaluasi dapat memfokuskan usha yang dilakukan. Jika anda tahu bahwa anda akan dinilai berdasarkan kriteria tertentu, maka anda akan lebih memfokuskan usaha anda pada hal-hal yang menjadi prioritas pencapaian tujuan.

2. Evaluasi menunjukkan keefektifan pelaksana kampanye dalam merancang dan mengimplementasikan programnya. Bila dalam suatu program kampanye anda berhasil menunjukkan keefektifan kerja, maka itu akan meningkatkan kredibilitas anda sebagai pelaksana kampanye (campaign organizer).

3. Memastikan efisiensi biaya. Kampanye selalu melibatkan biaya besar, dan penyelenggara kampanye tidak ingin dana dan berbagai sumber daya lain terbuang sia-sia.

4. Realistis, jelas dan terarah. Di sini berbagai hal yang tidak relevan akan dengan cepat diidentifikasi dan langsung disingkirkan.

5. Membantu akuntabilitas (pertanggungjawaban) pelaksanaan kampanye. Dalam hal ini pelaksana kampanye dapat mempertanggungjawabkan segala kebijakan. Tindakan bahkan rancangan kampanye yang tak terpisahkan, dimulai dari perencanaan yang meliputi analisis situasi dan konseptualisasi desain kampanye, dilanjutkan dengan tahap pelaksanaan yang merupakan penerapan dan penyesuaian dari rancangan yang telah dibuat, kemudian diakhiri dengan evaluasi yang ditujukan untuk menilai keefektivan kampanye.

Disamping ke 5 point di atas, yang perlu juga diperhatikan manager politik adalah waktu pelaksanaan kampanye dan dana pelaksanaan kampanye. Waktu pelaksanaan kampanye dilakukan jauh-jauh hari sebelum waktu atau jadwal kampanye yang ditetapkan oleh komisi pemilihan umum. Waktu pelaksanaan kampanye baik melalui media atau pamflet-pamflet secara tidak kasat mata. Misalnya, secara dini membentuk Ormas, walau tidak bisa dipungkiri bahwa Ormas sering menjadi Partai Pemilu.

Perlu diperhatikan waktu pelaksanaan kampanye yang sifatnya terus menerus agar masyarakat ingat, misalnya, melakukan bakti sosial di lingkungan masyarakat, ikut memberikan bantuan untuk pembangunan sekolah, tempat ibadah, bantuan beasiswa, dan lain-lain. Di samping itu, 
pertemuan rutin di lapisan pertama birokrat baik legislatif, eksekutif dan judikatif.

Tidak kalah penting adalah dana sebab jika tidak ada dana, apapun rencana yang dibuat untuk menghantar Komunikator Politik menjadi presiden, tidak dapat terealisasi tanpa didukung oleh dana yang mencukupi. Biarlah Manager Kampanye tetap menggunakan hati nurani ketika ingin memilih Komunikator Politik yang berwawasan kenegaraan.

\section{Daftar Pustaka}

Alfian \& Nazaruddin Sjamsuddin. 1991. Profil Budaya Politik Indonesia. Jakarta: PT Pustaka Utama Grafitti Untuk Asosiasi Ilmu Politik Indonesia.

Almond, Gabriel, A. 1984. Budaya Politik. Jakarta: Penerbit Bina Aksara.

Ardial. 2010. Komunikasi Politik. Jakarta: Permata Puri Media.

Bahari, Adib. 2009. KPK Komisi Pemberantasan Korupsi dari A Sampai Z. Yogyakarta: Pustaka Yustisia.

Budihardjo, Miriam. 1993. Dasar-Dasar Ilmu Politik. Jakarta: Penerbit PT Gramedia

Cangara, Hafied. 2009. Komunikasi Politik. Jakarta: PT Rajagrafindo Persada.

Djaya, Ermansyah. 2010. Memberantas Korupsi Bersama KPK. Jakarta: Sinar Grafika.

Harun, Rochajat. 2006. Komunikasi Politik Sebagai Suatu Pengantar. Bandung: Penerbit Mandar Maju.

Hikmat, Mahi M. 2010. Komunikasi Politik Teori dan Praktek, Bandung: Simbiosa Rekatama Media

McQuail, Dennis. 1991. Teori Komunikasi Massa: Suatu Pengantar. Diterjemahkan Aminuddin Ram. Jakarta: Erlangga.

Nimmo, Dan. 1989. Komunikasi Politik Khalayak dan Efek. Bandung: Penerbit PT Remaja Rosdakarya.

1993. Komunikasi Politik, Komunikator, Pesan, dan Media, Bandung: Penerbit PT Remaja Rosdakarya.

Pawito. 2009. Komunikasi Politik Media Massa dan Kampanye Pemilihan. Yogyakarta: Jalasutra.

Venus, Antar. 2009. Manajemen Kampanye. Bandung: Simbiosa Rekatama Media. 